\title{
ПРОФЕСІЙНА АДАПТАЦІЯ ФЕЛЬДШЕРІВ-ПОЧАТКІВЦІВ НА РОБОЧОМУ МІСЦ НА СТАНЦІї НЕВІДКЛАДНОЇ ДОПОМОГИ
}

\author{
о. В. Рожелюк
}

\author{
Одеське обласне базове медичне училище
}

У статті висвітлено основні проблеми у професійній адаптації випускників зі спеціальності «Лікувальна справа» на станції невідкладної допомоги.

\section{PROFESSIONAL ADAPTATION OF PARAMEDICS BEGINNERS AT WORK ON EMERGENCY STATION}

\author{
O. V. Rozhelyuk \\ Odesa Regional Basic Medical College
}

The article shows the main problems at professional adaptation graduates of the specialty Paramedics on energy station.

Вступ. Проблема забезпечення населення високоякісною швидкою та невідкладною медичною допомогою в даний час має не лише медичне, але й загальносоціальне значення (Б. В. Михайлов, О. І. Сердюк, А. О. Мартиненко, М. В. Маркова, 2000; Н. О. Марута, 2003 та ін.). В останні роки особлива увага приділяється психологічному забезпеченню професійної діяльності. З'являється все більше робіт, спрямованих насамперед на вивчення соціальної та поведінкової професійної адаптації (І. М. Тихонська, Г. Д. Дарій, О. А. Добродняк, 2000; А. В. Абрамов, В. Л. Олефиренко, 2001; В. В. Кришталь, 2002; В. Л. Гавенко, Г. А. Самардакова, Г. М. Кожина, 2002; Л. М. Юр'єва, 2004; М. П. Беро, 2006; В. В. Чугунов, 2008 та ін.) [1].

Одна з головних цілей сучасної вищої медичної освіти полягає в тому, щоб за допомогою різних форм навчання й виховання підготувати студента до плідної творчої участі у житті суспільства і діяльності в сфері охорони здоров'я. Сучасний медичний фахівець повинен не тільки адаптуватися до стрімких соціальних змін, але і вміти практично оцінити те, що відбувається і намітити шляхи подальших перетворень у сфері діяльності та в своєму житті.

Отже, вища освіта повинна створювати умови для формування вільної особистості, спілкування, розу-

(C) О. В. Рожелюк, 2017 міння інших людей, нарешті практичних дій і вчинків людини, тобто для розвитку людини як такої: і знаючої, і переживаючої, і духовної, і особистості.

Основна частина. Навчання фельдшерів у медичному училищі відбувається згідно з навчальними планами і навчальними програмами, затвердженими МO3 України в 2011 р. Підготовка випускників зі спеціальності «Лікувальна справа» відповідає вимогам освітньо-професійних програм і кваліфікаційним характеристикам. Однак на практиці спостерігається відсутність співвідношення теоретичної підготовки до медичних вимог надання якісної професійної допомоги пацієнтам. Саме це і стало причиною наших досліджень виявленої проблеми. Виникла професійна необхідність з'ясувати всі тонкощі та допомогти молодим спеціалістам у вирішенні професійного дискомфорту.

Фельдшер невідкладної допомоги одна із ключових фігур на станції швидкої невідкладної допомоги. Виїжджаючи на виклик самостійно (таке трапляється часто), фельдшер повинен прийняти правильне, професійно виважене рішення, надати домедичну допомогу, врятувати життя постраждалому. Прибувши на місце виклику, він з перших секунд зобов'язаний оцінити стан хворого, постраждалого, визначити об'єм необхідної допомоги, терміново приступити до її надання. 
Велике значення в роботі фельдшера в будь-якій складній оточуючій ситуації мають поведінкові фактори. Він повинен опанувати себе, поводитись спокійно, врівноважено, дії повинні бути чіткі, швидкі, професійно впевнені. Враховуючи специфіку роботи, фельдшер повинен володіти також навичками психолога. Навчальна дисципліна «Основи медичної психології та міжособове спілкування» забезпечує початковий рівень знань з психології. На нашу думку, цих знань недостатньо. Бажано з цієї спеціальності розширити зміст дисципліни.

Співвідношення виїжджаючих бригад на користь фельдшерських приблизно 70 \%, тому вимоги до лікарських і фельдшерських бригад практично однакові:

- робота з обладнанням (дихальна апаратура, зняття ЕКГ, дефібрилятори);

- досконале володіння медичною термінологією;

- постійно на контролі етика та деонтологія;

- більше уваги потребує нормативна документація (протоколи).

Головним лікарем Одеської міської станції швидкої медичної допомоги приділяється велика увага молодим спеціалістам, створюються умови для професійної адаптації на робочому місці. Визначається професіоналізм і впевненість у виборі професії. За результатами анкетування в перші місяці роботи з'ясовується, що професія фельдшера вибрана свідомо, вмотивовано і за покликом серця.

На основі спостережень колег-лікарів швидкої, старших фельдшерів і аналізуючи їхні побажання щодо підготовки фельдшерів у медичних навчальних

\section{СПИСОК ЛІТЕРАТУРИ}

1. Вороненко Ю. В. Аналіз проблем кадрового забезпечення первинної медичної допомоги в контексті реформування галузі охорони здоров'я в Україні / Ю. В. Вороненко, Н. Г. Гойда, О. Г. Шекера // Здоров'я суспільства. - 2013. - Т. 2, № 2. - С. 14-21.

2. Калайтан Н. Л. Особенности эмоционального реагирования на стрессовые факторы членов бригад ско- закладах зроблено висновки: в навчальній програмі дисципліни «Акушерство» збільшити години на відпрацювання практичних навичок із тактики ведення вагітних та надання їм допомоги; з дисципліни «Реаніматологія та анестезіологія» збільшити години на відпрацювання практичних навичок: реанімаційні дії, надання медичної допомоги відповідно до протоколів.

У цілому варто відзначити, що навчальна програма зі спеціальності «Лікувальна справа» задовольняє вимоги сучасної практичної медицини щодо підготовки фельдшерів до роботи на станціях швидкої медичної допомоги. Випускники Одеського обласного базового медичного училища психологічно готові до посади фельдшера швидкої медичної допомоги, більшість з них назавжди залишаються вірними вибраній професії і вже не залишають іï.

Висновки. Сучасний фахівець у галузі медицини (медсестра, фельдшер, лікар) повинен володіти значним запасом спеціальних психолого-педагогічних знань, вміти поповнювати, розвивати і творчо застосовувати їх у професійній діяльності. Виконуючи будь-які професійні функції, людина завжди реалізує себе як особистість, цілісно реагуючи на певні ситуації, вступаючи у взаємодію з іншими учасниками професійної діяльності, водночас формуючи систему індивідуальних цінностей. Саме відсутність готовності до виконання професійних обов'язків не дозволяє значній частині випускників повністю реалізувати свій творчий потенціал, утруднює процеси соціальної та професійної адаптації, перешкоджає оволодінню високими рівнями професійної майстерності.

рой медицинской помощи / Н. Л. Калайтан, Б. С. Федак, В. М. Загуровский // Медицина неотложных состояний. 2007. - № 2 (9). - С. 53-56.

3. Федак Б. С. Синдром выгорания у медицинских работников / Б. С. Федак // Медицинская психология. 2007. - № 3. - С. 18-22. 